\title{
Effects of Involvement in Religious Organization on Youth Development
}

\author{
FRANCES MAE C. TRABAJO \\ http://orcid.org/0000-0001-8471-9730 \\ rheeka_trabajo@universityofbohol.edu.ph
}

\begin{abstract}
The collaborative efforts of the church, the school, and the family are a potent force in designing new programs and activities that are appealing, able to sustain interest and youth involvement. This study aimed to describe the personal "growth experiences" gained by youth participants in the Youth Encounter (YE) program of the Catholic Youth Ministry (CYM). The study centered on the apostolate of the Diocesan Youth Ministry in the Diocese of Talibon, Bohol, Philippines. One hundred fifty Roman Catholic youth respondents, aged 15 to 16 years of age were randomly selected from the 43 parishes in the Diocese of Talibon. Percentages and weighted mean were used to analyze and interpret the data. The findings illustrated how the program influenced the emotional, social and spiritual growth of the youth participants. The Fully Evident rating on Affirmation, Discovering one's true identity and Self-worth signifies personal growth and change in the youth's character, attitudes, and beliefs. The findings showed positive outcomes in the youth's personal "growth experiences," participation in the program ensures learning opportunities and ownership of personal development. A program with supportive adults enables the youth to learn appropriate competencies and skills that will eventually lead to positive development.
\end{abstract}

Keywords: Social Science, youth development, religious involvement, quantitative method, weighted mean, Philippines, Asia 


\section{INTRODUCTION}

Today's youth, afflicted by many issues and dilemmas in life, are somewhat viewed in a negative light. Mass media, vices, drugs, materialism, and absence of parental guidance and interventions are seen as contributory factors that hinder healthy development. However, the Roman Catholic Church recognizes the potential role of the youth as future leaders and resources of our nation. In one of his messages, Pope Francis stressed the vital role and responsibilities of the youth, encouraging them to be passionate agents in the transformation of society. He urged families, educational and church institutions to work together in shaping the youth's total development.

The Catholic Church in the Philippines, through the "Youth Encounter" program, tries its best to reach out to the Filipino youth. The program's mission is to aid youth participants to process their own personal growth experiences and to discover experiences that enrich their self-worth and dignity as a person. The primary objective is to foster youth development in terms of value formation, spiritual, social, emotional and moral growth. The implementation of the program is seen as an instrument to connect and inspire young people. Despite its good intentions, the youth ministry felt dismayed by the Filipino youth's lack of enthusiasm and involvement in the program. In the survey of Sandoval, Mangahas, and Guerrero (1998), the results depicted the Filipino youth as very religious and prayerful and who regularly attended religious services regularly. However, they are not joiners of religious organizations.

Research studies demonstrate that active involvement in religious organization transpires in positive youth development. Fagan (2006) reveals that participation in religious organizations bolsters favorable selfimage and significantly affects the level of wellbeing. Youth interaction with adults, peers, and parents shaped with trust and supportive relationships will have a substantial influence on moral development (King and Furrow, 2008). In the studies of Wallace (1998) and Hill, Burdette, Ellison, \& Musick (2006), the religious participation of youth is associated with positive, healthy behaviors and reduction of risky behaviors such substance abuse, alcoholism, smoking, school drop-outs and promiscuous sexual activities. Smith (2003) revealed that religious participation among American youth influenced constructive attitudes and behaviors 
As seen from such studies, involvement or participation in religious organizations is a powerful deterrent to risk-seeking behavior. Considering the lack of enthusiasm from Filipino youths in joining such organizations, religious organizations should evaluate existing programs and activities to set new directions that can encourage more youth involvement. The collaborative efforts of religious organizations, educational institutions, and the family are a potent force in designing new programs and activities that are appealing, able to sustain interest and youth involvement.

The Youth Encounter program (or the Virac Model) was started by Rev. Msgr. Jose B. Molina in Virac, Catanduanes in 1971. It is a formation module for Catholic youth meant to train the youth or youth ministers who work among the young. This scripture-based program sees participants share experiences, engage in prayer and other activities to affirm their role as bearers of the faith in the church and society.

This study aims to describe the personal "growth experiences" gained by youth participants in the Youth Encounter (YE) program of the Catholic Youth Ministry (CYM).

\section{METHODOLOGY}

The study centers on the apostolate of the Diocesan Youth Ministry in the Diocese of Talibon, Bohol, Philippines. One hundred fifty (150) youth participants were randomly selected from the 43 parishes in the Diocese of Talibon. The participants were mostly Roman Catholics with ages ranging from 15-16 years old.

The research tool specifically described the personal "growth experiences" gained by the participants in relation to emotional, social and spiritual aspects. The Likert style of item construction was adapted to identify the perceived personal "growth experiences" gained. The constructed items for personal growth experiences were anchored on the purposes and objectives of the Youth Encounter program. Statistical techniques were used to determine the percentages, weighted mean and composite mean to support the analysis and interpretation of data.

\section{RESULTS AND DISCUSSION}

The findings illustrated how the program influenced the emotional, social and spiritual growth of the youth participants. 
Table 1. Personal "growth experiences" gained in relation to emotional aspect

$\mathrm{N}=15$

\begin{tabular}{|l|c|c|}
\hline \multicolumn{1}{|c|}{ Items } & $\begin{array}{c}\text { Weighted } \\
\text { Mean }\end{array}$ & Description \\
\hline $\begin{array}{l}\text { 1. Joy of accepting oneself, one's strength and } \\
\text { weaknesses }\end{array}$ & 3.46 & Fully Evident \\
\hline $\begin{array}{l}\text { 2. Happy to know one's true identity and self-worth } \\
\text { 3. Inspired to communicate in the person level or feeling } \\
\text { level }\end{array}$ & 3.55 & Fully Evident \\
\hline $\begin{array}{l}\text { 4. Faithful in relating with one another in care, trust and } \\
\text { openness }\end{array}$ & 3.40 & Fully Evident \\
\hline 5. Experience of joy to affirm and be affirme & 3.61 & Fully Evident \\
\hline 6. Serene acceptance of problems and pains in life & 3.16 & Moderately Evident \\
\hline 7. Sensitive to the needs and feelings of others & 3.25 & Moderately Evident \\
\hline 8. Feeling grateful and appreciative & 3.53 & Fully Evident \\
\hline $\begin{array}{l}\text { 9. Assured of the future with a renewed vision and } \\
\text { commitment in life }\end{array}$ & 3.39 & Fully Evident \\
\hline Composite mean & 3.41 & Fully Evident \\
\hline
\end{tabular}

Hall (1904) defined adolescence as a time of "storm and stress," a formative period where young people go through intense emotional and behavioral turmoil. These biological and psychological dilemmas experienced at this stage need to be surpassed and resolved to allow the youth to establish a stable equilibrium and maturity (Arnett, 2006). The Fully Evident rating on Experience of joy to affirm and be affirme and Happy to know one's true identity and self-worth signifies personal growth and change in the youth's character, attitudes, and beliefs.

Table 2. Personal "growth experiences" gained in relation to social aspect $N=150$

\begin{tabular}{|ll|c|c|}
\hline \multicolumn{1}{|c|}{ Items } & $\begin{array}{c}\text { Weighted } \\
\text { Mean }\end{array}$ & Description \\
\hline 1. & Relate with one another in an affirming relationshi & 3.27 & Fully Evident \\
\hline 2. Strong desire to do away rejection in the community & 3.19 & Moderately Evident \\
\hline $\begin{array}{l}\text { 3. } \\
\begin{array}{c}\text { Participate in the activities of the Parish Youth } \\
\text { Ministry and other religious and civic } \\
\text { organizations }\end{array}\end{array}$ & 2.83 & Moderately Evident \\
\hline 4. $\quad$ Watching news and public affairs & 3.29 & Fully Evident \\
\hline
\end{tabular}




\begin{tabular}{|c|c|c|}
\hline $\begin{array}{l}\text { 5. Render voluntary service in the school or in the } \\
\text { barangay }\end{array}$ & 2.80 & Moderately Evident \\
\hline $\begin{array}{l}\text { 6. Living out the three elements of personhood in the } \\
\text { community: free, loving and responsible }\end{array}$ & 3.14 & Moderately Evident \\
\hline $\begin{array}{l}\text { 7. Strong desire to live the YE dream and challenge: } \\
\text { Remove "crowd" and build community! }\end{array}$ & 3.31 & Fully Evident \\
\hline $\begin{array}{l}\text { 8. Determined to finish studies and earn a dignifie } \\
\text { living }\end{array}$ & 3.82 & Fully Evident \\
\hline Composite mean & 3.21 & Moderately Evident \\
\hline
\end{tabular}

The findings also revealed the youths' convictions, confidence and caring relationship as reflected in the Fully Evident ratings on the following items: Determined to finish studies and earn a dignified living; Strong desire to live the YE dream and challenge; Watching news and public affairs and Relate with one another in an affirming relationship. These findings are further associated with how the program influenced youth outlook and values. In the study of Andolina, Jenkins, Zukin, \& Keeter (2003), religious institutions are acknowledged as one of the significant role models who can reinforce active youth civic engagement.

Table 3. Personal "growth experiences" gained in relation to spiritual aspect $\mathrm{N}=150$

\begin{tabular}{|ll|c|c|}
\hline \multicolumn{2}{|c|}{ Items } & $\begin{array}{c}\text { Weighted } \\
\text { Mean }\end{array}$ & Description \\
\hline 1. Inspired to read and reflect the ord of God & 3.17 & Moderately Evident \\
\hline 2. Deepened knowledge of God & 3.28 & Fully Evident \\
\hline 3. Develop personal prayer & 3.45 & Fully Evident \\
\hline 4. $\quad$ Committed to attend Holy Mass every Sunday & 3.09 & Moderately Evident \\
\hline 5. Strengthened faith in God & 3.64 & Fully Evident \\
\hline 6. Value silence and internalization & 3.23 & Moderately Evident \\
\hline 7. Handle problems with God & 3.47 & Fully Evident \\
\hline 8. Devotion to Mary & 2.86 & Moderately Evident \\
\hline 9. $\quad$ Transformed by God & 3.21 & Moderately Evident \\
\hline Composite mean & 3.27 & Fully Evident \\
\hline
\end{tabular}

True to its mission, the objectives of the Youth Encounter program successfully guided youth participants in their spiritual journey as indicated 
in the following Fully Evident ratings: 1. Strengthened faith in God, 2. Handle problems with God, 3. Develop personal prayer, and 4. Deepened knowledge of God. It is interesting to note that the experience of faith strongly influenced the youth's desire to deepen their relationship with God as this finding confirms the study of Steen $(2003$, ) where youth participants considered spirituality in one's own belief of a supreme being or a Christian God.

\section{CONCLUSION}

The findings showed that positive outcomes in the youth's personal "growth experiences," participation in the program ensured learning opportunities and ownership of personal development. A program with supportive adults usually enables the youth to learn appropriate competencies and skills that will eventually lead to positive development.

The program certainly provides experiential learning opportunities; it even prescribes and fosters proficiencies to help the youth deal with adolescence crisis. It is a challenge to the ministry to design measures on how to promote the program to increase youth's participation. In the conceptualization of the new design, the Catholic Youth Ministry should learn about a relatively new approach of understanding youth psychology.

The Theory of Youth Positive Development posits that recognition of the youth's unique potentials and talents is likely to produce better outcomes instead of dwelling on their weaknesses (Lerner, Phelps, Forman, \& Bowers, 2009). A supportive environment that freely allows the youth to express their ideas and demonstrate their talents is an excellent partner of the ministry; together they can work hand in hand in inspiring other youth to get involved in the program.

\section{REFERENCES CITED}

Andolina, M. W., Jenkins, K., Zukin, C., \& Keeter, S. (2003). Habits from home, lessons from school: Influences on youth civic engagement. Political Science and Politics, 36(02), 275-280. Retrieved from http://goo.gl/ dBvtBN.April, (accessed last 16 April 2015).

Arnett, J. J. (2006). G. Stanley Hall's Adolescence: Brilliance and nonsense. History of psychology, 9(3), 186.Retrieved from http://goo.gl/Qrs4wC, (accessed last 14 April 2015). 
Ebstyne King, P., \& Furrow, J. L. (2008). Religion as a resource for positive youth development: religion, social capital, and moral outcomes. In Meeting of the Society for Research in Child Development, Apr, 2001, Minneapolis, MN, US; A previous version of this article was presented at the aforementioned conference. (No. 1, p. 34). Educational Publishing Foundation. Retrieved from http://goo.gl/xEL8NS, (accessed last 30 March 2015).

Fagan, P. F. (2006). Why religion matters even more: The impact of religious practice on social stability. Heritage Foundation Backgrounder, (1992). Retrieved from http://goo.gl/FNzE2E, (accessed last 15 April 2015).

Hill, T. D., Burdette, A. M., Ellison, C. G., \& Musick, M. A. (2006). Religious attendance and the health behaviors of Texas adults. Preventive medicine, 42(4), 309-312.Retrieved from http://goo.gl/vhH3xh, (accessed last 16 April 2015).

Lerner, J. V., Phelps, E., Forman, Y. E., \& Bowers, E. P. (2009). Positive youth development. John Wiley \& Sons Inc. Retrieved from http://goo. gl/1sydO8, (accessed last 16 April 2015).

Pope Francis' Message to Filipino Youth. Meeting with the Youth University of Santo Tomas 18 January 2015. http://globalnation.inquirer.net/117611/ message-of-pope-francis-to-filipino-youth-at-ust/ Retrieved fro http://goo.gl/uTA8zm, (accessed last 30 March 2015).

Sandoval, G., Mangahas, M., Guerrero, L. L., \& Stations, S. W. (1998). The situation of Filipino youth: A national survey. Age, 15(17), 27. Retrieved from http://goo.gl/hluxyB, (accessed last 30 March 2015).

Smith, C. (2003). Religious participation and network closure among American adolescents. Journal for the Scientific Study of Religion, 42(2), 259-267.Retrieved from http://goo.gl/OCeWvh, (accessed last 30 March 2015).

Steen, T. A., Kachorek, L. V., \& Peterson, C. (2003). Character strengths among youth. Journal of youth and adolescence, 32(1), 5-16. Retrieved from http://goo.gl/NOu578, (accessed last 16 April 2015).

Wallace, J. M., \& Forman, T. A. (1998). Religion's role in promoting health and reducing risk among American youth. Health Education \& Behavior, 25(6), 721-741. Retrieved from http://goo.gl/hZCX7W), (accessed last 30 March 2015). 